UDC $351.74: 342.922$

DOI: $10.31733 / 2078-3566-2019-5-79-84$

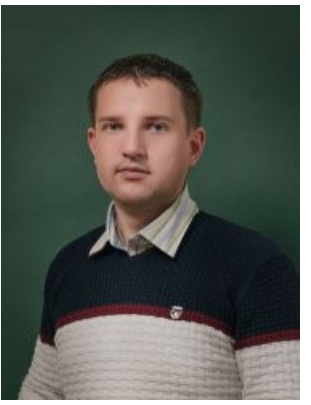

Yevhen LEHEZA ${ }^{\circledR}$

Dr of Law, Ass. Prof.

(University of Customs and Finance, Dnipro)

\title{
ANALYSIS OF SCIENTIFIC CONCEPTS AND THE LEGAL \\ FRAMEWORK OF THE CONCEPT OF INFORMATION SUPPORT FOR ADMINISTRATIVE LEGAL PROCEEDINGS
}

Євген Легеза. АНАЛІЗ НАУКОВИХ КОНЦЕПЦІЙ ТА ПРАВОВИХ ЗАСАД КОНЦЕПЦІЇ ІНФОРМАЦЙНОГО ЗАБЕЗПЕЧЕННЯ АДМІНІСТРАТИВНОГО СУДОЧИНСТВА. Стаття присвячена аналізу наукових концепцій та правових засад концепції інформаційного забезпечення адміністративного судочинства. Вивчаються особливості надання інформації для адміністративного судочинства; підкреслено його відмінності від інформаційного забезпечення адміністративного суду. Запропоновано авторські визначення поняття інформаційного забезпечення адміністративної процедури та інформаційного забезпечення адміністративного суду. Виокремлено три етапи формування національного законодавства, що регулює інформаційне забезпечення адміністративного судочинства. Уточнено систему законів та нормативно-правових актів, положення яких закріплюють правові основи інформаційного забезпечення адміністративного судочинства. Розкрито перспективні напрями розвитку наукового дослідження у сфері інформаційного забезпечення адміністративного судочинства та його правового регулювання.

Визначені умовні етапи формування правового регулювання інформаційного забезпечення адміністративного судочинства грунтувалися на подіях, що мають ключове значення для формування системи інформаційного забезпечення адміністративного судочинства, $\mathrm{i}$ супроводжувалися вторинними фрагментарними змінами, які стосувалися лише інформаційне забезпечення окремих видів адміністративних справ.

При дослідженні інформаційного забезпечення адміністративного судочинства необхідно відрізняти його від інформаційного забезпечення адміністративного суду. Інформаційне забезпечення адміністративного суду $\epsilon$ частиною адміністративної діяльності щодо аналізу, планування та підготовки управлінських рішень, що $\epsilon$ безперебійним процесом обробки та використання інформації про стан функціонування апарату суду та робота суддів, яка здійснюється за допомогою інформаційних засобів та методів, призводить до формування інформаційних фондів і спрямована на забезпечення належного функціонування адміністративного суду. У той же час, як інформаційне забезпечення адміністративного судочинства України, це, виходячи з вимог чинного національного законодавства, $є$ сукупністю заходів, пов'язаних з обігом процесуальної інформації, що реалізуються в рамках своїх функцій уповноваженими агентами та через функціонування автоматизованих систем та спрямовані на забезпечення належного функціонування адміністративних судів з розгляду та вирішення публічно-правових спорів.

На сучасному етапі розвитку вітчизняного законодавства правове регулювання інформаційного забезпечення адміністративного судочинства здійснюється відповідно до таких законів та нормативноправових актів: Закони України «Про судоустрій та статус суддів», «Про внесення змін до деяких Законодавчі акти України щодо впровадження автоматизованої системи документації в адміністративних судах »; «Про доступ до судових рішень», «Про внесення змін до Господарського процесуального кодексу України, Цивільного процесуального кодексу України, Кодексу адміністративного судочинства України та інших законодавчих актів», Кодексу адміністративного судочинства України, а також Положення «Про автоматизовану систему документообігу суду», Порядок ведення Єдиного державного реєстру судових рішень, Положення про Єдину базу даних електронних адрес, факс-номерів (телефонів) органів влади. Деякі аспекти інформаційного забезпечення адміністративного судочинства України регулюються на рівні підзаконних актів, прийнятих Державною судовою адміністрацією України, які затверджують Типові інструкції щодо роботи працівників адміністрації місцевого загального суду; Інструкція про порядок роботи 3 технічними засобами ведення судового провадження (судові засідання); Інструкція з управління справами в адміністративних судах тощо.

Ключові слова: адміністративна юрисдикиія, адміністративне судочинство, адміністративна процедура, правила судів, предмет.

(C) Leheza Ye., 2019

https://orcid.org/0000-0001-9134-8499

https://www.scopus.com/authid/detail.uri?authorId $=57200152533$

www.researcherid.com/rid/X-9904-2019

yevhenleheza@gmail.com 
Problem statement. Article's objective. For the effective functioning of the state and all state mechanisms, information provision of administrative legal proceedings of Ukraine is of key importance. As V. B. Pchelin notes, the proper functioning of administrative legal proceedings of Ukraine, within which the consideration and resolution of public-law disputes related to the protection and restoration of violated, unrecognized, disputed rights, freedoms, and interests of individuals and legal entities take place, may be only in the case of its effective information support [7]. The content and scope of information relations arising in the field of administrative legal proceedings with each stage of development of domestic information and procedural legislation are increasingly specified. At the same time, the growth of the circle of such relations, the increase of the types of information used within the administrative legal proceedings, and the growing importance of information support for administrative legal proceedings are observed. The current legal community of Ukraine is looking for ways to optimize the work of the entire judicial system in general and administrative legal proceedings in particular.

Basic content. The volume of cases handled by administrative courts remains significant every year. Thus, in 2016, 215319 administrative cases were received for consideration by local administrative courts, and 76184 cases - by administrative courts of appeals. In 2017, 121692 cases were submitted for consideration to the local administrative courts and 73496 cases - to the administrative courts of appeal. Accordingly, the amount of information used to resolve such a circle of cases invariably grows; the need for optimization of information databases, their integration, and improving the efficiency of the search for the necessary information increases.

Legal fundamentals of information provision of administrative legal proceedings in Ukraine and the stages of their formation. In the dictionaries, the term «provision» is interpreted in similar terms, but they have certain differences. Thus, in the new explanatory dictionary of the Ukrainian language, it is considered in two meanings: 1) the provision or creation of material resources; 2) guaranteeing something [12]. In the great explanatory dictionary, the term «provision» is explained through the verb «to provide», which is used in several meanings: «to create reliable conditions for the implementation of something»; «to guarantee something»; «to defend, to protect someone, anything from danger». The above interpretation of the concept of «provision» allows considering it as an activity, a system of measures aimed at improving something specific. So, one can agree with the conclusion of V.B. Pchelin that the category of «provision» is denoted by a long process aimed at guaranteeing the functioning of the relevant institu [8].

The term «provision» can be used in various areas of legal regulation and have some peculiarities depending on it. However, for the purpose of studying the issues of information provision of administrative legal proceedings, the results of the search of scientists are important in terms of approaches to the content of the concept of information provision. So, R. A. Kaliuzhnyi, investigating information provision of a management system, proposes to understand it as a combination of all the information used, specific means and methods of its processing, as well as the activities of specialists on the efficient use of data, information, knowledge in the management of a particular system [5, p. 11]. Studying the information provision of management, S.M. Petrenko believes that it is a set of implemented decisions on the volumes of information, its qualitative and quantitative composition, location, and forms of organization, the purpose is timely provision of necessary and sufficient information for the adoption of managerial decisions that ensure the effective operation of both the enterprise as a whole and its structural subdivisions [9, p. 20].

O.K. Yudin and V.M. Bohush, studying the provision of information security, define it as a set of measures designed to achieve the state of protection of the needs of individuals, society, and the state in information [12, p. 52].

Directly informational support as an independent concept, L. V. Balabanova proposes to understand as a set of actions to provide the necessary management information in the specified place on the basis of certain procedures with a given periodicity [3, p. 9]; A. V. Chernoivanenko - as a system for managing the totality of representations, concepts, data, and as activities related to means of collecting, registering, transmitting, storing, processing, and presenting information [4].

Under the legal principles of information provision of administrative legal proceedings, V.B. Pchelin proposes to understand the totality of legal acts of various legal force, which, taking into account their hierarchical links, carry out statutory regulation of the activities of authorized entities and the functioning of automated information systems with the operation of 
information in order to ensure proper activities of administrative courts for the consideration and resolution of public-law disputes.

The current state of legal regulation of information provision of administrative legal proceedings preceded the long period of development of domestic administrative-procedural and information legislation. The general principles of information provision of administrative legal proceedings are determined by the following laws of Ukraine: «On Personal Data Protection» on June 1, 2010; «On Court Fees» on July 8, 2011; «On Appeal of Citizens» on October 2, 1996;

«On State Secrets» on January 21, 1994; «On Electronic Documents and Electronic Document Circulation» as of May 22, 2003; «On Electronic Digital Signature» on May 22, 2003; «On Information » dated October 2, 1992; «On Access to Public Information» on January 13, 2011; «On Information Protection in Information and Telecommunication Systems» dated July 5, 1994; etc. Special laws and regulations detail the order of information provision of administrative legal proceedings.

The stages of formation of the legal regulation of information provision of administrative legal proceedings, determined by us, are based on large-scale structural changes that have led to global processes in the field of information provision of administrative legal proceedings.

We associate the first stage of the formation of legislation regulating the information provision of administrative legal proceedings with the adoption of the Code of Administrative Legal Proceedings of Ukraine (hereinafter referred to as CALP) on July 6, 2005. Thus, the first edition of the CALP identified such important components of the information provision of administrative legal proceedings as the principles of transparency and openness of the administrative process (Article 12), the principles of recording the court session by technical means (Article 41), reproduction and printing of the technical record of the court session (Article 44); types of procedural information and its carriers.

The second stage of the formation of legal norms regulating information provision of administrative legal proceedings is connected with the introduction of an automated system of document circulation in administrative courts. The Law of Ukraine «On Amendments to Certain Legislative Acts of Ukraine Regarding the Introduction of Automated System of Document Circulation in Administrative Courts» on June 5, 2009, No. 1475-VI supplemented the CALP by Art. 15-1 «Automated System of Court Documents». By the Order of the State Judicial Administration of Ukraine as of 03.12.2009 $\mathrm{N}^{\circ}$ 129, the provision «On Automated System of Document Circulation in Administrative Courts» [2] was approved, which expired pursuant to the Decision of the Council of Judges of Ukraine as of 26.11.2010 No. 30, which introduced the Regulation on the Automated System of Document Circulation of the Court [2].

The second stage in the formation of information provision of administrative legal proceedings is also characterized by a fragmentary development of certain rules regulating the information provision of certain categories of administrative cases. One of such legal acts, which caused changes in this area, is the Law of Ukraine «On Amendments to Certain Legislative Acts of Ukraine on Elections of the President of Ukraine» as of August 21, 2009, No 1616-VI, which identified the features of the use of procedural information under the proceedings in cases related to the election of the President of Ukraine. The Law of Ukraine «On Alienation of Land Plots and Other Immovable Property Located Thereon, Which are in Private Property, for Public Needs or Social Necessity» on November 17, 2009, N 1559-VI, supplemented the CALP by Article 183-1 «Peculiarities of the Proceedings in Administrative Cases Concerning the Compulsory Alienation of a Land Plot, Other Objects», this article defines a circle of procedural information characteristic for this category (The Legislation of Ukraine, 2009). Also, at this stage, there was an extension of the circle of legal norms regulating the information provision of certain stages and types of proceedings in administrative legal proceedings (Article 174, Article 183-2 of the CALP), the circle of information used in administrative legal proceedings was expanded, etc.

At this stage, the formation of the legal regulation of the information provision of administrative legal proceedings also introduces changes to Art. 12 «Publicity and Openness of Administrative Process» regarding the recording of the trial by technical means.

The third stage of the formation of the legislation regulating information provision of administrative legal proceedings began on November 22, 2017, with the signing of the Law of Ukraine «On Amendments to the Commercial Procedural Code of Ukraine, the Civil Procedural Code of Ukraine, the Code of Administrative Legal Proceedings of Ukraine, and other legislative acts». This stage is characterized by the introduction of the electronic justice system at all stages of the process and the transition to the Single Judicial Information and Telecom- 
munication System, the creation of the possibility of remote participation in the trial, the presentation of various documents, familiarization with the case. The specified system provides for the exchange of documents in electronic form between courts, between the court and participants in the trial, as well as recording the trial and participation of participants in the court proceedings in a court session in a video conferencing mode.

In accordance with the said law, the system of organization of legal proceedings in Ukraine undergoes certain changes, namely: obligatory registration of procedural documents in the system on the day they are received; committing any actions in electronic form using an electronic digital signature; automatic determination by the system of a judge or panel of judges for consideration of a particular case in accordance with the procedure established by the Codes; storage of case materials in electronic form; preservation of the right of the parties to the case to apply to the court in paper form and receive the relevant documents after the introduction of the system; obligation to broadcast a court session in a video conferencing mode via the Internet; functioning of the Unified State Register of Executive Documents [10]. The information provided indicates the phased development of the legal norms that are in the CALP and regulate the information relations in the administrative legal proceedings.

Conclusions. The conditional stages of the formation of the legal regulation of the information provision of administrative legal proceedings determined by us were based on events of key importance for the formation of the information support system of administrative legal proceedings and were accompanied by secondary fragmentary changes that concerned only information provision of certain types of administrative cases.

When investigating the information support of administrative proceedings, it is necessary to distinguish it from the information support of the administrative court. In our view, the information support of the administrative court is a part of the administrative activity for the analysis, planning, and preparation of management decisions, which is an uninterrupted process of processing and using information on the state of functioning of the court apparatus and work of judges, which is carried out with the help of information tools and methods, leads to the formation of information funds, and is aimed at ensuring the proper functioning of the administrative court. At the same time, as information provision of administrative legal proceedings of Ukraine, this is, based on the requirements of the current national legislation, a set of measures related to the circulation of procedural information, which are implemented in the framework of their functions by authorized agents and through the functioning of automated systems and aimed at ensuring the proper functioning of administrative courts on consideration and resolution of public-law disputes.

At the current stage of development of domestic legislation, the legal regulation of information provision of administrative legal proceedings is carried out in accordance with the following laws and regulations: Laws of Ukraine «On the Judiciary and Status of Judges», «On Amendments to Certain Legislative Acts of Ukraine on the Introduction of Automated System of Documentation in Administrative Courts»; «On Access to Court Decisions», «On Amendments to the Commercial Procedural Code of Ukraine, the Civil Procedural Code of Ukraine, the Code of Administrative Justice of Ukraine, and other legislative acts», the Code of Administrative Legal Proceedings of Ukraine, as well as the Regulation «On Automated System of Documentation of the Court», the Procedure for the Management of the Single State Register of Court Decisions, the Regulation on the Single Database of Electronic Addresses, Fax Numbers (Telefaxes) of the Authorities. Some aspects of the information provision of administrative legal proceedings of Ukraine are regulated at the level of subordinate legislation adopted by the State Judicial Administration of Ukraine, which approve the Typical Job Instructions for Employees of the Administration of the Local General Court; Instruction on the Procedure for Working with Technical Means of Recording Court Proceedings (Court Sessions); Instruction on Case Management in Administrative Courts, etc.

The nearest changes in the system of information provision of the administrative process in accordance with the Action Plan on the implementation of the Law of Ukraine as of 03.10.2017 $\mathrm{N}^{\circ}$ 2147-VIII «On Amendments to the Commercial Procedural Code of Ukraine, the Civil Procedural Code of Ukraine, the Code of Administrative Legal Proceedings of Ukraine, and other legislative acts» is the introduction of the Unified State Register of Executive Documents and the Single Judicial Information and Telecommunication System.

\section{References}

1. Про автоматизовану систему документообігу в адміністративних судах: Наказ Державної судової адміністрації України від 3 грудня 2009 р. № 129. Офіційиний вісник Украӥни. 
2010. № 101. С. 393. Ст. 3566. (втратив чинність на підставі наказу Державної судової адміністрації № 195 від 15.12.2010)

2. Про відчуження земельних ділянок, інших об'єктів нерухомого майна, що на них розміщені, які перебувають у приватній власності, для суспільних потреб чи з мотивів суспільної необхідності: Закон України від 17 листопада 2009 р. № 1559-VI. Відомості Верховної Ради Украӥни. 2010. № 1. С. 3. Ст. 2.

3. Балабанова Л.В., Алачева Т.И. Информационное обеспечение обосно- вания управленческих решений в условиях маркетинговой ориентации пред- приятия: монография. Донецк: ДонГУЭТ им. М. Туган-Барановского, 2003. 143 с.

4. Черноіваненко А.В., Галунько В.В. Інформаційне забезпечення підготовки, прийняття та реалізації управлінських рішень: теоретичний підхід до визначення поняття. URL: http://www.kbuapa.kharkov.ua/e-book/conf/2009-1/doc/35.pdf.

5. Калюжний Р.А., Гавловський В.В., Гуцалюк М.А. та ін. Інформаційному суспільству України інформаційне законодавство (щодо питань реформувань у сфері суспільних інформаційних відносин). Правове, нормативне та метрологічне забезпечення системи захисту інформації в Україні. 2001. № 2. С. 7-11.

6. Новий тлумачний словник української мови: в 4 т. / уклад.: В.В. Яременко, О.М. Сліпушко. Київ: Аконіт, 1999. 941 с.

7. Пчелін В.Б. Сутність інформаційного забезпечення адміністративного судочинства в Україні. Науковий вісник Ужгородського начіонального університету. Серія «Право». 2016. № 39. C. $22-25$.

8. Пчелін В.Б. Перегляд адміністративних актів органів внутрішніх справ: дис. ... канд. юрид. наук: 12.00.07 / Харків. нац. ун-т внутр. справ. Харків, 2011. 190 с.

9. Петренко С.М. Інформаційне забезпечення внутрішнього контролю господарських систем: монографія. Донецьк: ДонНУЕТ, 2007. 290 с.

10. Роїк О.В. Електронне судочинство. Чи має Україна шанси? URL: http://yurgazeta.com/dumka-eksperta/elektronne-sudochinstvo-chi-mae-ukrayina-shansi.html.

11. Щодо Положення про автоматизовану систему документообігу суду: Рішення Ради суддів України від 26 листопада 2010 р. № 30. Вісник Верховного Суду Украӥни. 2010. № 51. С. 5.

12. Юдін О.К., Богуш В.М. Інформаційна безпека держави: навч. посібник. Харків: Консум, 2005. $576 \mathrm{c.}$

Received to editorial office 29.11.2019

1. Pro avtomatyzovanu systemu dokumentoobihu v administratyvnykh sudakh [On the Automated Document Management System in Administrative Courts]: Nakaz Derzhavnoyi sudovoyi administratsiyi Ukrayiny vid 3 hrudnya 2009 r. № 129. Ofitsiynyy visnyk Ukrayiny. 2010. № 101. S. 393. St. 3566. (vtratyv chynnist' na pidstavi nakazu Derzhavnoyi sudovoyi administratsiyi № 195 vid 15.12.2010). [in Ukr.]

2. Pro vidchuzhennya zemel'nykh dilyanok, inshykh ob"yektiv nerukhomoho mayna, shcho na nykh rozmishcheni, yaki perebuvayut' u pryvatniy vlasnosti, dlya suspil'nykh potreb chy $\mathrm{z}$ motyviv suspil'noyi neobkhidnosti [On alienation of land plots and other immovable property on private property for public or public use reasons]: Zakon Ukrayiny vid 17 lystopada 2009 r. № 1559-VI. Vidomosti Verkhovnoyi Rady Ukrayiny. 2010. № 1. S. 3. St. 2. [in Ukr.]

3. Balabanova, L. V., Alacheva, T. I. (2003) Informatsyonnoye obespecheniye obosnovaniya uravlencheskikh resheniy $\mathrm{v}$ usloviyakh marketingovoy orientatsii predpriyatiya [Informational support of management decisions under conditions of enterprise marketing orientation]: monografiya. Donetsk: DonGUÉT im. M. Tugan-Baranovskogo, 143 s. [in Russ.]

4. Chernoivanenko, A. V., Halun'ko, V. V. Informatsiyne zabezpechennya pidhotovky, pryynyattya ta realizatsiyi upravlins'kykh rishen': teoretychnyy pidkhid do vyznachennya ponyattya [Informational support for the preparation, adoption and implementation of management decisions: a theoretical approach to the definition of the concept]. URL: http://www.kbuapa.kharkov.ua/e-book/conf/20091/doc/35.pdf. [in Ukr.]

5. Kalyuzhnyy, R. A., Havlovs'kyy, V. V., Hutsalyuk, M. A. ta in. (2001) Informatsiynomu suspil'stvu Ukrayiny informatsiyne zakonodavstvo (shchodo pytan' reformuvan' u sferi suspil'nykh informatsiynykh vidnosyn) [Information Law of the Information Society of Ukraine (on reform issues in the field of public information relations)]. Pravove, normatyvne ta metrolohichne zabezpechennya systemy zakhystu informatsiyi v Ukrayini. № 2. S. 7-11. [in Ukr.]

6. Novyy tlumachnyy slovnyk ukrayins'koyi movy [New interpretative dictionary of the Ukrainian language]: v 4 t. / uklad.: V.V. Yaremenko, O.M. Slipushko. Kyyiv: Akonit, 1999. 941 s. [in Ukr.]

7. Pchelin, V. B. (2016) Sutnist' informatsiynoho zabezpechennya administratyvnoho sudochynstva v Ukrayini [The essence of information support of administrative justice in Ukraine]. Naukovyy visnyk Uzhhorods'koho natsional'noho universytetu. Seriya «Pravo». № 39. S. 22-25. [in Ukr.]

8. Pchelin, V. B. (2011) Perehlyad administratyvnykh aktiv orhaniv vnutrishnikh sprav [Revision of administrative acts of law enforcement agencies]: dys. ... kand. yuryd. nauk: 12.00.07 / Kharkiv. nats. un-t vnutr. sprav. Kharkiv, 190 s. [in Ukr.]

9. Petrenko, S. M. (2007) Informatsiyne zabezpechennya vnutrishn'oho kontrolyu hospodars'kykh system [Information support of internal control of economic systems]: monohrafiya. Donets'k: DonNUET, 290 s. [in Ukr.] 
10. Royik O. V. Elektronne sudochynstvo. Chy maye Ukrayina shansy? [Electronic Judiciary. Does Ukraine have any chance] URL: http://yur-gazeta.com/dumka-eksperta/elektronne-sudochinstvochi-mae-ukrayina-shansi.html. [in Ukr.]

11. Shchodo Polozhennya pro avtomatyzovanu systemu dokumentoobihu sudu [Concerning the Regulation on the automated system of court circulation]: Rishennya Rady suddiv Ukrayiny vid 26 lystopada 2010 r. № 30. Visnyk Verkhovnoho Sudu Ukrayiny. 2010. № 51. S. 5. [in Ukr.]

12. Yudin, O. K., Bohush, V. M. (2005) Informatsiyna bezpeka derzhavy [Information Security of the State]: navch. posibnyk. Kharkiv: Konsum,. 576 s. [in Ukr.]

\section{Summary}

The article is devoted to the analysis of scientific concepts and the legal framework of the concept of information support for administrative legal proceedings. Features and peculiarities of information provision for administrative legal proceedings are studied; its differences from information support for the administrative court are stressed. The author's definitions of the concept of information support for the administrative procedure and information support for the administrative court are proposed. Three stages of formation of national legislation regulating information provision of administrative legal proceedings are singled out. The system of laws and regulations, which provisions consolidate legal fundamentals of information support for administrative legal proceedings, is clarified. Prospective directions for the development of scientific inquiry in the field of information support for administrative legal proceedings and its legal regulation are revealed.

The conditional stages of the formation of the legal regulation of the information provision of administrative legal proceedings determined by us were based on events of key importance for the formation of the information support system of administrative legal proceedings and were accompanied by secondary fragmentary changes that concerned only information provision of certain types of administrative cases.

Keywords: administrative jurisdiction, administrative legal proceedings concept, administrative procedure, courts rules, subject.

UDC 342.95

DOI: $10.31733 / 2078-3566-2019-5-84-90$

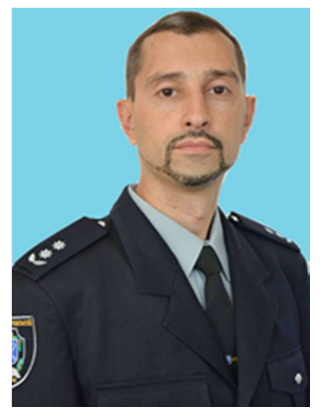

Andriy

SOBAKAR ${ }^{\circ}$

Dr of Law, Prof.
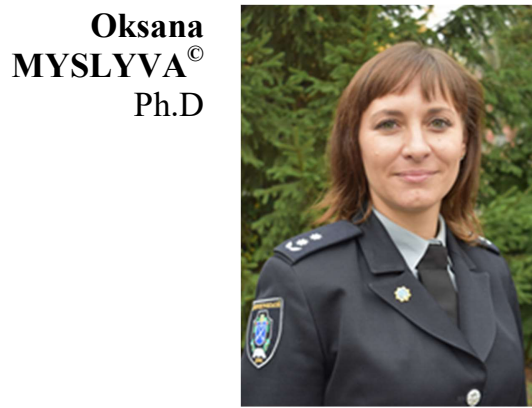

(Dnipropetrovsk State University of Internal Affairs)

\section{MEASURES TO ENSURE PROCEEDINGS IN ADMINISTRATIVE OFFENSES THAT RESTRICT PROPERTY RIGHTS}

Андрій Собакарь, Оксана Мислива. ЗАХОДИ ЗАБЕЗПЕЧЕННЯ ПРОВАДЖЕННЯ У СПРАВАХ ПРО АДМІНІСТРАТИВНІ ПРАВОПОРУШЕННЯ, ЩО ОБМЕЖУЮТЬ НЕМАЙНОВІ ПРАВА. В Україні передбачено чимало адміністративно-правових інструментів охорони правопорядку, захисту прав та інтересів громадян, в переліку яких особливе місце займають заходи забезпечення провадження у справах про адміністративні правопорушення. Їх застосування реалізує припинення адміністративних проступків, встановлення особи порушника, складання протоколу про адміністративне правопорушення, забезпечення своєчасного і правильного розгляду справи, забезпечення виконання постанов у справах про адміністративні правопорушення, документування факт доказів його вчинення. Останнім часом законодавство зазнало суттєвих змін у

(C) Sobakar A., 2019

ORCID iD: https://orcid.org/0000-0002-7618-0031

aasobakar77@ukr.net

(C) Myslyva O., 2019

ORCID iD: https://orcid.org/0000-0002-0181-9603

omaxah@gmail.com 